\title{
Interstitial pneumonitis in patients infected with the human immunodeficiency virus
}

M H Griffiths, R F Miller, S J G Semple not itself lead directly to the patient's death. It does, however, appear to mark a downturn in the course of HIV infection. (Thorax 1995;50:1141-1146)

Keywords: interstitial pneumonitis, non-specific interstitial pneumonitis, HIV, AIDS.

Methods - A retrospective review was made of the case notes, chest radiographs, and histopathological results of seven HIV1 antibody positive patients with symptomatic diffuse pulmonary disease and a pathological diagnosis of non-specific interstitial pneumonitis.

Results - All patients had dyspnoea, with or without cough, and chest radiographs showing diffuse infiltrates. The arterial oxygen tension ranged widely from 5.9 to $13 \cdot 1 \mathrm{kPa}$. The initial clinical diagnosis was Pneumocystis carinii pneumonia in most cases. The pathological diagnosis was made by transbronchial biopsy in one case and by open lung biopsy in six cases. The interstitial pneumonitis consisted of a patchy lymphocytic infiltrate composed of $B$ cells in focal aggregates and $T$ cells in a more diffuse distribution. The $T$ cell population was a mixture of CD4+ and CD8 + cells. The histological findings contrast with the more extensive infiltrate of predominantly CD8 + lymphocytes seen in HIV-associated lymphocytic interstitial pneumonitis which occurs mainly in children. The condition ran a subacute course. Three patients spontaneously improved and three improved with steroid therapy. Long term survival was less than three years, the prognosis being determined by other infective or neoplastic complications.

Conclusions - Non-specific interstitial pneumonitis usually presents with an illness resembling Pneumocystis carinii pneumonia but occurs when the CD4 and total lymphocyte counts are still preserved. The pneumonitis resolves spontaneously or responds to steroids, and does
Pulmonary disease is a common feature of HIV infection and is often the first indication of the onset of AIDS. The clinical differential diagnosis in a patient presenting with dyspnoea who has diffuse radiological pulmonary infiltrates includes bacterial infection, pneumocystis pneumonia, cryptococcal pneumonia, and pulmonary Kaposi's sarcoma, all of which are life-threatening conditions for which specific forms of therapy are appropriate. Bacterial, pneumocystis, and cryptococcal pneumonia are usually diagnosed by examination of sputum, induced sputum, or bronchoalveolar lavage fluid. ${ }^{1}$ If these investigations fail to yield a diagnosis it may be necessary to proceed to open lung biopsy as some conditions, such as atypical pneumocystis infection ${ }^{23}$ and Kaposi's sarcoma, may only be diagnosed by this procedure. ${ }^{4}$ It was in this clinical setting that our seven patients presented.

\section{Methods}

The seven patients were all homosexual Caucasian men of mean age 41 years (range 35-56). Two patients had cutaneous Kaposi's sarcoma. The remainder had none of the criteria for a diagnosis of AIDS but all were known to be $\mathrm{HIV}$ antibody positive for periods ranging from 12 to 53 months before their hospital admission for diagnosis. All seven patients complained of breathlessness; five also complained of cough (table 1). The duration of the symptoms was, in most cases, only a few weeks but, in two patients, the duration was three and seven months. Three of the patients were nonsmokers. Crackles on auscultation of the chest was the only abnormal physical sign elicited

Medical School

University College

London Hospitals

Trust and Camden

and Islington

Community Services

Trust, Middlesex

Hospital, London, UK

R F Miller

S J G Semple

Reprint requests to

Dr M H Griffiths.

Received 21 December 1994

Returned to authors

6 April 1995

Revised version received

1 June 1995

Accepted for publication

31 July 1995

\begin{tabular}{|c|c|c|c|c|c|c|}
\hline \multirow{2}{*}{$\begin{array}{l}\text { Patient } \\
\text { no. }\end{array}$} & \multicolumn{2}{|c|}{ Symptoms } & \multirow{2}{*}{$\begin{array}{l}\text { Duration } \\
\text { (weeks) }\end{array}$} & \multirow{2}{*}{$\begin{array}{l}\text { Initial } \\
\text { clinical } \\
\text { diagnosis }\end{array}$} & \multirow{2}{*}{$\begin{array}{l}\text { Prior } \\
\text { AIDS } \\
\text { diagnosis }\end{array}$} & \multirow{2}{*}{$\begin{array}{l}\text { Duration known to } \\
\text { be HIV antibody }+ \text { ve } \\
\text { (months) }\end{array}$} \\
\hline & Cough & Dyspnoea & & & & \\
\hline 1 & + & + & 4 & PCP & None & 18 \\
\hline 2 & - & + & 12 & PCP & None & 12 \\
\hline 3 & + & + & 2 & None & None & 53 \\
\hline 4 & + & + & 3 & PCP & None & 24 \\
\hline 5 & - & + & 3 & Pulmonary KS & Cutaneous and & 36 \\
\hline 6 & + & + & 30 & PCP & None & 24 \\
\hline 7 & + & + & 4 & PCP & Cutaneous KS & 33 \\
\hline
\end{tabular}

$\mathrm{PCP}=$ Pneumocystis carinii pneumonia; $\mathrm{KS}=$ Kaposi's sarcoma. 
Table 2 Investigations

\begin{tabular}{|c|c|c|c|c|c|}
\hline \multirow{2}{*}{$\begin{array}{l}\text { Patient } \\
\text { no. }\end{array}$} & \multicolumn{2}{|c|}{ Arterial blood gases $(\mathrm{kPa})$} & \multicolumn{2}{|c|}{ Lymphocyte counts $\left(\times 10^{9} / l\right)$} & \multirow[t]{2}{*}{ Chest radiographic abnormalities } \\
\hline & $\mathrm{PaO}_{2}$ & $\mathrm{PaCO}_{2}$ & $\begin{array}{l}C D 4 \\
(0 \cdot 35-2 \cdot 2)\end{array}$ & $\begin{array}{l}\text { Total } \\
(1 \cdot 0-4 \cdot 0)\end{array}$ & \\
\hline $\begin{array}{l}1 \\
2 \\
3 \\
4 \\
5 \\
6 \\
7\end{array}$ & $\begin{array}{r}10 \cdot 4 \\
5 \cdot 9 \\
13 \cdot 1 \\
11 \cdot 3 \\
\mathrm{ND} \\
9 \cdot 1 \\
11 \cdot 4\end{array}$ & $\begin{array}{l}4 \cdot 8 \\
4 \cdot 4 \\
4 \cdot 8 \\
4 \cdot 5 \\
\text { ND } \\
4 \cdot 8 \\
3 \cdot 9\end{array}$ & $\begin{array}{l}\text { ND } \\
\text { ND } \\
0 \cdot 62 \\
\text { ND } \\
\text { ND } \\
0 \cdot 42 \\
0 \cdot 17\end{array}$ & $\begin{array}{l}0 \cdot 84 \\
1 \cdot 60 \\
2 \cdot 40 \\
4 \cdot 20 \\
1 \cdot 20 \\
4 \cdot 40 \\
1 \cdot 20\end{array}$ & $\begin{array}{l}\text { Reticular, diffuse } \\
\text { Reticular nodular, diffuse } \\
\text { Reticular, diffuse; mass right hilum } \\
\text { Perihilar loss of translucency and lung markings } \\
\text { Reticular nodular, basal; left pleural effusion } \\
\text { Reticular, diffuse; hilar gland enlargement } \\
\text { Perihilar loss of translucency and lung markings }\end{array}$ \\
\hline
\end{tabular}

$\mathrm{ND}=$ not done.

except in one patient (no. 5) who had a pleural effusion.

Routine haematological and biochemical blood tests and chest radiographs were performed on all patients on admission. In addition, all patients had induced sputum examinations and fibreoptic bronchoscopy with bronchoalveolar lavage. None of these investigations established a diagnosis and, in particular, no evidence of Pneumocystis carinii infection or endobronchial Kaposi's sarcoma was found. Every patient had an abnormal chest radiograph but the changes were usually slight and non-specific (table 2) with two main patterns of abnormality - reticular nodular, and a fine perihilar generalised loss of radiolucency with loss of the normal lung markings. Comparison with the descriptive terms used in much of the radiological literature suggests that the term "reticular nodular shadowing" used in this paper would be termed "interstitial infiltrates", and "diffuse loss of radiolucency with loss of lung markings" would be "alveolar infiltrates (grade I or II)". Most of the radiographs were compatible with a diagnosis of pneumocystis pneumonia. Additional findings were a mass at the right hilum (patient 3), mediastinal hilar gland enlargement (patient 6), and a left pleural effusion (patient 5).

The arterial gas tensions were either normal or showed mild hypoxaemia while breathing air. The exception was a patient admitted with an exacerbation of longstanding asthma who was severely hypoxaemic with an abnormal arterial carbon dioxide tension (patient 2). Treatment with bronchodilators and prednisolone partially corrected the hypoxaemia.

In three patients the CD4 lymphocyte count was measured and was found to be normal in two cases and modestly reduced in the third (table 2). The total lymphocyte count was within the normal range for all patients except one in whom it was just below the normal range.
In five patients the initial clinical diagnosis was pneumocystis pneumonia, though it was appreciated that the normal or near normal CD4 count or total lymphocyte count was atypical for that diagnosis. Two of the patients had an empirical course of treatment for pneumocystis pneumonia with no improvement before lung biopsy.

Four of the seven patients had transbronchial biopsies and in one (patient 4 ) the diagnosis of non-specific interstitial pneumonitis was made. In the other three the histological findings were inconclusive. These three, together with the remaining patients with negative bronchoscopic investigations, proceeded to open lung biopsy. The lung tissue in all cases was processed, paraffin embedded in routine fashion, and stained by conventional techniques which included Ziehl-Neelsen, PAS, and Grocott's silver methenamine for acid fast bacilli and fungi, respectively. Immunoperoxidase preparations on paraffin sections were performed for the following leucocyte markers: CD20 for B lymphocytes, CD3 and CD45 RO (UCHL1) for T cells, CD4 for T helper/ inducer cells, CD8 for $\mathrm{T}$ cytotoxic/suppressor cells, CD21 for dendritic reticulum cells, and CD28 for macrophages. Immunostaining was also performed for cytomegalovirus (CMV) and herpes simplex viruses (HSV) 1 and 2 . Epstein-Barr virus (EBV) was sought by immunostaining for latent membrane protein and, in three cases, by in situ hybridisation using an EBER oligonucleotide on paraffin sections. Studies for HIV were not undertaken on tissue sections for technical reasons.

\section{Results}

The lung pathology was characterised by an interstitial infiltrate of mature lymphocytes, plasma cells, and macrophages (table 3 ). In two cases (nos 2 and 3 ) there were also scattered eosinophils in the infiltrate. The lymphocytes

Table 3 Histopathological results

\begin{tabular}{lllllll}
\hline $\begin{array}{l}\text { Patient } \\
\text { no. }\end{array}$ & $\begin{array}{l}\text { Severity of } \\
\text { infiltrate } \\
\text { (grades 1-3) }\end{array}$ & $\begin{array}{l}\text { B cells } \\
\text { (CD20) }\end{array}$ & $\begin{array}{l}\text { Germinal } \\
\text { centres } \\
\text { (CD21) }\end{array}$ & $\begin{array}{l}\text { T cells } \\
(C D 3 \text { and } \\
C D 45 \text { RO) }\end{array}$ & $\begin{array}{l}\text { Ratio of } \\
C D 8 \text { to } C D 4 \\
\text { cells }\end{array}$ & $\begin{array}{l}\text { Other } \\
\text { histological } \\
\text { features }\end{array}$ \\
\hline 1 & 2 & Focal & ND & Diffuse & $1: 0$ & Patchy intra-alveolar haemorrhage \\
2 & 2 & ND & ND & ND & ND & Focal BOOP \\
3 & 3 & Focal & Present & Diffuse & ND & BOOP \\
4 & 2 & Focal & Absent & Diffuse & $3: 2$ & $1: 1$ \\
5 & 1 & Focal & Present & Diffuse & $1: 1$ & \\
6 & 1 & Focal & Present & Diffuse & $1: 2$ & \\
7 & 2 & Focal & Present & Diffuse & $3: 2$ & \\
\hline
\end{tabular}

$\mathrm{ND}=$ not done; $\mathrm{BOOP}=$ bronchiolitis obiterans organising pneumonia. 


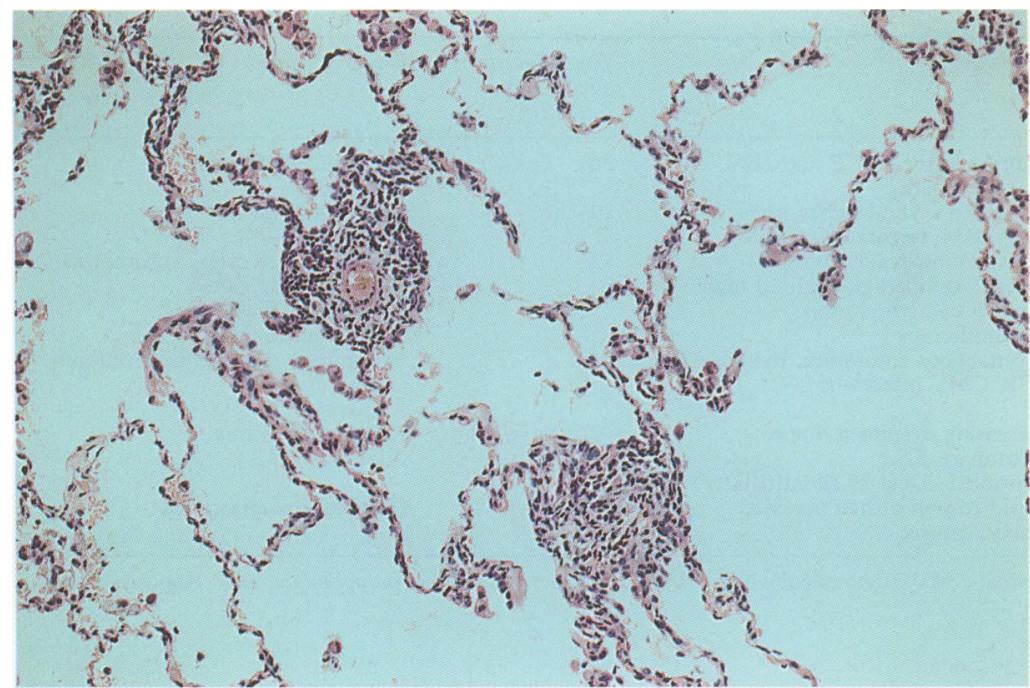

Figure 1 Lung biopsy specimen showing mild non-specific interstitial pneumonitis at low power. Aggregates of lymphocytes are found in the interstitium, especially around vessels, and there are collections of macrophages in alveolar spaces. Magnification $\times 100$.
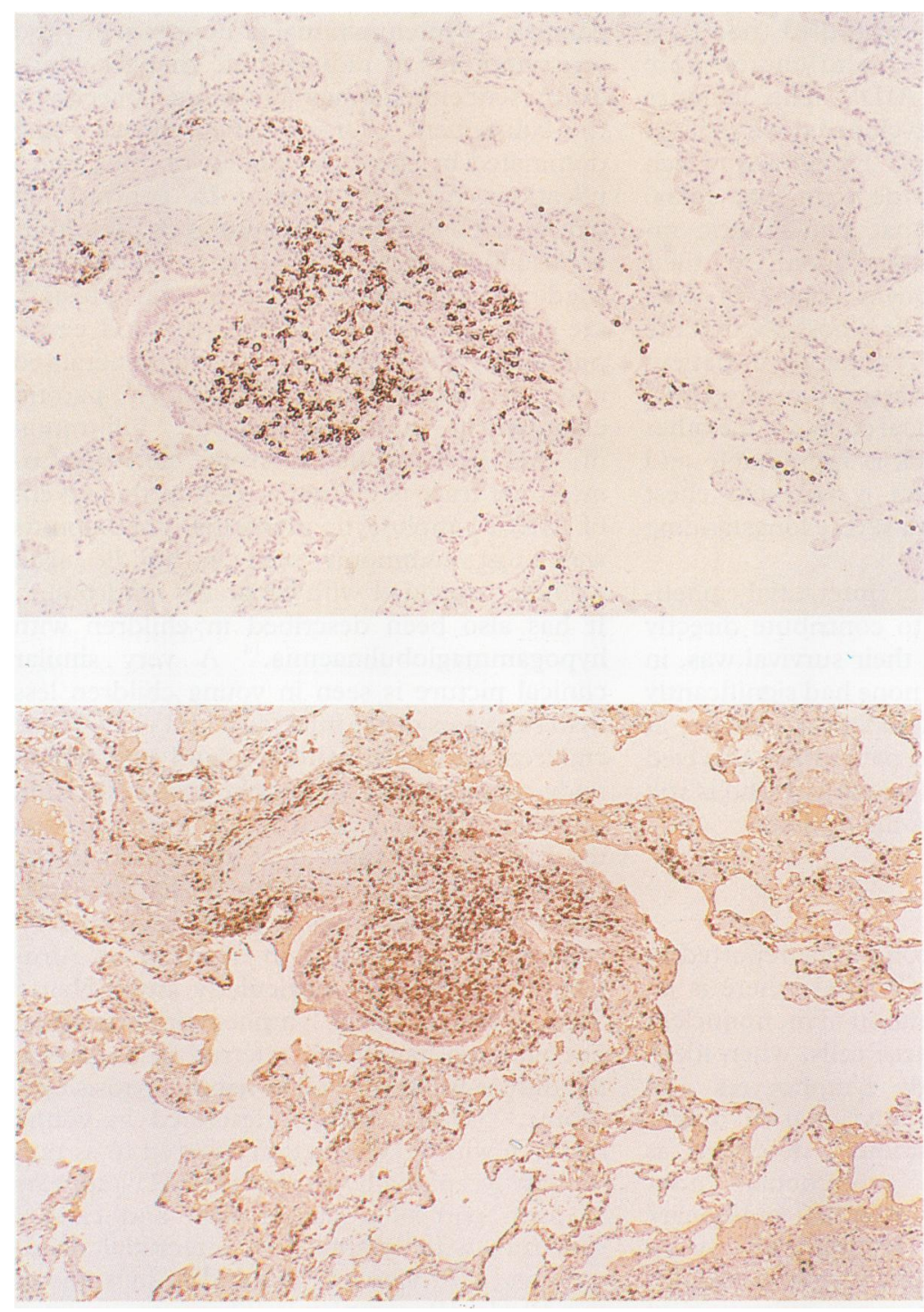

Figure 2 (A) Lung biopsy specimen showing non-specific interstitial pneumonitis at higher power stained with antibody $C D 20$ showing a peribronchiolar, perivascular aggregate of $B$ cells. $(B)$ Same field as in $(A)$ stained with $C D 3$ showing a more diffuse infiltrate of $T$ cells. Magnification $\times 250$. were found in aggregates in bronchiolar walls and perivascular areas (fig 1) and in interlobular and subpleural connective tissue. When the infiltrate was more extensive it extended into the alveolar septa. Approximately $50 \%$ of the cells within these aggregates were CD20 + B lymphocytes (fig 2A). Follicles, identified by the presence of clusters of CD21 + dendritic reticulum cells, had formed in some of these aggregates. Mixed with the B cell aggregates and extending from them was a more diffuse infiltrate of T cells (fig 2B) which were CD4+ and $\mathrm{CD} 8+$ in approximately equal numbers. In two cases there was a slight preponderance of CD8 cells over CD4 cells, and in one case (no. 1) no CD4 + cells were found. The severity of the infiltrate varied from mild and patchy (nos 5 and 6) to severe (no. 3), but was never as extensive or as dense as is seen in lymphocytic interstitial pneumonia. There was no cytological atypia which might have suggested the presence of lymphoma. Oedema fluid and collections of macrophages had accumulated in the alveoli in the vicinity of the interstitial infiltrates and in the bronchioles. Pigment was often present in the cytoplasm of the macrophages and some had formed giant cells. In patient no. 3 there was patchy intra-alveolar organisation of the type seen in bronchiolitis obliterans with organising pneumonia (BOOP). This was also present focally in patient no. 2. Type II pneumocyte hyperplasia was often seen where the alveolar interstitium was expanded by oedema or cellular infiltrates. There were no granulomas. Stains for acid fast bacilli, pneumocystis, and other fungi were negative.

No CMV or HSV was detected immunohistochemically in the six cases examined. In one case there was insufficient tissue for viral studies. EBV latent membrane protein was negative in six cases but EBV was detected in one of the three cases examined by in situ hybridisation (no. 7), a few scattered positive cells being present in the lymphocytic infiltrate.

Three patients received prednisolone and in two there was an apparent rapid beneficial response to treatment with clearing of the chest radiographs (table 4). In one of these two (no. 6 ) the TLCo and Kco (which had been $64 \%$ and $56 \%$ of predicted) rose to normal levels, and that patient remains alive 29 months later. The third patient who received prednisolone (no. 2) had long term asthma. There was an initial improvement after which his condition remained stable for a few weeks; thereafter he pursued a relentlessly downhill course with increasing respiratory failure and recurrent bacterial chest infections.

In two patients (nos 3 and 4 ) their condition resolved spontaneously, whilst in a third patient (no. 1) there was a reduction in the severity of his dyspnoea and the frequency of his cough but he remained mildly symptomatic. In one patient (no. 5) the course of the illness and the cause of death was attributed to pulmonary and pleural Kaposi's sarcoma. This was not proven as a necropsy was not performed, but he had widespread cutaneous Kaposi's sarcoma and extensive bilateral leg oedema secondary 


\begin{tabular}{|c|c|c|c|c|}
\hline $\begin{array}{l}\text { Patient } \\
\text { no. }\end{array}$ & $\begin{array}{l}\text { Treated with } \\
\text { prednisolone }\end{array}$ & Follow up & $\begin{array}{l}\text { Time to death } \\
\text { after biopsy } \\
\text { (months) }\end{array}$ & Cause of death \\
\hline 1 & No & $\begin{array}{l}\text { Improved, then PCP and HIV } \\
\text { encephalopathy }\end{array}$ & 26 & $\begin{array}{l}\text { HIV encephalopathy. } \\
\text { Septicaemia }\end{array}$ \\
\hline 2 & Yes & $\begin{array}{l}\text { Stable for several weeks, then } \\
\text { progressive respiratory failure }\end{array}$ & 9 & Respiratory failure \\
\hline 3 & No & $\begin{array}{l}\text { Spontaneous resolution } \\
\text { Later developed generalised high } \\
\text { grade B cell lymphoma } \\
\text { Chemotherapy }\end{array}$ & 32 & $\begin{array}{l}\text { *Right carotid artery thrombosis. } \\
\text { Cerebral infarction. } \\
\text { No residual lymphoma. } \\
\text { No pneumonitis }\end{array}$ \\
\hline 4 & $\begin{array}{l}\text { No } \\
\cdot\end{array}$ & $\begin{array}{l}\text { Spontaneous resolution, then MAI, } \\
\text { PCP, CMV infections }\end{array}$ & 32 & $\begin{array}{l}\text { *Suppurative bronchopneumonia } \\
\text { and pleurisy. } \\
\text { Residual PCP }\end{array}$ \\
\hline 5 & No & $\begin{array}{l}\text { Increasing dyspnoea due to } \\
\text { pulmonary } \mathrm{KS}\end{array}$ & 2 & $\begin{array}{l}\text { Respiratory failure. } \\
\text { Pulmonary KS }\end{array}$ \\
\hline 6 & Yes & Improved. Alive 29 months later & - & \\
\hline 7 & Yes & $\begin{array}{l}\text { Rapid response then cerebral } \\
\text { toxoplasmosis }\end{array}$ & 2 & Cerebral toxoplasmosis \\
\hline
\end{tabular}

$\mathrm{PCP}=$ Pneumocystis carinii pneumonia $\mathrm{CMV}=$ cytomegalovirus; $\mathrm{MAI}=$ Mycobacterium avium intracellulare $; \mathrm{KS}=\mathrm{Kaposi}$ 's sarcoma. * Necroscopic findings.

to Kaposi's sarcoma of the inguinal lymph glands. These findings, together with that of a large left pleural effusion, make it likely that the patient's dyspnoea and his subsequent respiratory failure and death were due to pulmonary Kaposi's sarcoma rather than nonspecific interstitial pneumonitis.

The subsequent illness and cause of death in five of the six patients who died (nos 1, 3, 4,5 , and 7) was plainly due to one or more of the complications of AIDS. This includes patient no. 3 who later developed disseminated high grade non-Hodgkin's lymphoma which presented as a mass in the right iliac fossa. There is no evidence that non-specific interstitial pneumonitis contributed to their deaths or to the subsequent course of their illnesses following biopsy. It is possible that the deterioration of respiratory function in patient no. 2 was caused by non-specific interstitial pneumonitis, but the clinical course of the other patients suggests that this is improbable and a more likely explanation is repeated chest infections in a patient with severe longstanding asthma.

Although non-specific interstitial pneumonitis did not appear to contribute directly to death in our patients, their survival was, in fact, very poor given that none had significantly reduced $\mathrm{CD} 4$ or total lymphocyte counts at the time of diagnosis. No patient has survived longer than 32 months. The patient who is still alive has survived 29 months to date.

\section{Discussion}

There are a number of conditions reported in patients infected with HIV where there is an infiltration and/or proliferation of mononuclear cells within the lung. These cells, when identified, are predominantly lymphocytes and plasma cells which are polyclonal in origin. These conditions are variously described as lymphocytic interstitial pneumonia, nonspecific interstitial pneumonitis, pulmonary lymphoid hyperplasia, lymphocytic bronchiolitis, and follicular bronchitis/bronchiolitis.

Non-malignant lymphocytic infiltration of the lung is not common in adults, whether infected by HIV or not. The two conditions most frequently described in association with
HIV infection are lymphocytic interstitial pneumonitis and non-specific interstitial pneumonitis. ${ }^{5-12}$ Lymphocytic interstitial pneumonitis is common in children and rare in adults, whilst non-specific interstitial pneumonitis has only been well characterised in adults. In non-specific interstitial pneumonitis there are few or no symptoms, the radiographic changes are often minimal or non-existent, and any symptoms or radiographic changes which are present either remain unchanged or regress, the subsequent course of their illness being dominated by the development of other complications of HIV disease. In contrast, in lymphocytic interstitial pneumonitis symptoms are usually moderate to severe, reticulonodular shadows, sometimes with a pleural effusion, are seen on the chest radiograph, and extrapulmonary involvement including generalised and mediastinal lymphadenopathy, parotid enlargement and lymphocytic infiltration of the liver, bone marrow, and gastrointestinal tract is common. Before the advent of AIDS, lymphocytic interstitial pneumonitis was most commonly seen in middle aged women associated with Sjögren's syndrome. ${ }^{13}$ It has also been described in children with hypogammaglobulinaemia. ${ }^{14} \mathrm{~A}$ very similar clinical picture is seen in young children less than two years of age infected by HIV. ${ }^{1516}$ These children also have salivary gland and lymph node enlargement and lymphocytic infiltration of other organs, and there is evidence that the Epstein-Barr virus may play a part in the development of this condition. ${ }^{16}{ }^{17}$ Lymphocytic interstitial pneumonitis is rarely seen in HIV infected adults, except in a group of AfroCaribbean patients particularly from Haiti. ${ }^{6}$ Some patients with lymphocytic interstitial pneumonitis have been referred to as having the diffuse infiltrative CD8 lymphocytosis syndrome. ${ }^{18}$ The condition described in young children with HIV infection referred to as pulmonary lymphoid hyperplasia (PLH) ${ }^{19}$ appears to form part of a pathological and clinical spectrum with lymphocytic interstitial pneumonitis (LIP) which is referred to by some as the PLH/LIP complex. ${ }^{16}$ There are isolated reports of lymphocytic bronchiolitis ${ }^{20}$ and follicular bronchitis/bronchiolitis. ${ }^{21}$ The pathological changes observed in lymphocytic 
bronchiolitis and follicular bronchitis/bronchiolitis would be compatible with those observed in a larger series of patients with non-specific interstitial pneumonitis, ${ }^{22}$ and it therefore seems reasonable to include the descriptions of lymphocytic bronchiolitis and follicular bronchitis/bronchiolitis in HIV infected patients as manifestations of non-specific interstitial pneumonitis.

Pathological changes which occur in both non-specific interstitial pneumonitis and lymphocytic interstitial pneumonitis include lymphoid infiltrates in peribronchial, perivascular, septal and pleural tissues - that is, in the distribution of the pulmonary lymphatics. The distinguishing feature of lymphocytic interstitial pneumonitis is the more substantial volume of the infiltrate which accounts for the radiologically more nodular appearance of the opacities. Histologically, in lymphocytic interstitial pneumonitis the infiltrate extends more widely into the alveolar septa and is usually associated with secondary type II pneumocyte hyperplasia. Nodular lymphoid aggregates with or without germinal centres may be seen in both non-specific interstitial pneumonitis and lymphocytic interstitial pneumonitis, and the distinction between these two conditions may not always be clearcut, especially with small transbronchial biopsy samples, and open lung biopsy may be necessary to substantiate a diagnosis. In these cases reference to the clinical and radiographic findings may help to distinguish one from the other. ${ }^{22}$

The phenotype of the lymphocytes has not been clearly defined in many of these conditions. We have shown the infiltrate in nonspecific interstitial pneumonitis to consist of a mixture of $T$ and $B$ lymphocytes, but the $B$ cells are aggregated in well defined groups related to blood vessels, bronchioles, interlobular septa, and subpleural connective tissue, whereas the $T$ cells are more diffusely arranged comprising the majority of lymphocytes found in the alveolar septa. The $T$ cells are a mixture of CD8 + and CD4 + cells. In the paper by Travis et $a l^{2}$ both $\mathrm{T}$ and $\mathrm{B}$ cells are described in non-specific interstitial pneumonitis but their relative distribution is not described.

What then is the cause of non-specific interstitial pneumonitis? It has now been well established by studies on bronchoalveolar lavage fluid that some patients with HIV infection develop a transient pulmonary lymphocytic alveolitis which may be asymptomatic. ${ }^{23-26}$ In this alveolitis bronchoalveolar lavage fluid lymphocytes are predominantly $\mathrm{T}$ lymphocytes, a finding not inconsistent with our observation of $\mathrm{T}$ cell predominance in the alveolar septa. In one study of 23 asymptomatic HIV infected adults with normal chest radiographs who were subjected to transbronchial biopsy, 11 had chronic non-specific interstitial pneumonitis. ${ }^{8}$ It seems likely therefore that lymphocytic alveolitis and non-specific interstitial pneumonitis are manifestations of the same condition, which is a relatively common association of HIV infection that is only occasionally symptomatic. Other studies on bronchoalveolar lavage fluid and lung biopsy specimens make it likely that the cause of this pneumonitis is the HIV itself and the immunological reaction to that virus. ${ }^{2227-30}$ There is no evidence from our work or from other studies that Epstein-Barr virus, cytomegalovirus, or herpes viruses play any part in this disorder.

Although non-specific interstitial pneumonitis has a good prognosis initially, survival in our patients has so far been less than 32 months despite normal CD4 or total lymphocyte counts at the time of diagnosis. Other series have shown similar short survival. Suffredini et $a l^{7}$ described 13 symptomatic patients with non-specific interstitial pneumonitis and no other initial lung disease. None was known to survive longer than 12 months although four of their patients were lost to follow up. It is possible that the onset of non-specific interstitial pneumonitis marks a downturn in the course of HIV infection.

An objective beneficial response to steroids has not been proven, but the impressive clinical response reported here and elsewhere in some patients justifies a clinical trial providing there is no contraindication.

1 Griffiths MH, Kocjan G, Miller RF, Godfrey-Faussett P. Diagnosis of pulmonary disease in human immunodeficiency virus infection: role of transbronchial biopsy and bronchoalveolar lavage. Thorax 1989;44:554-8.

2 Birley HDL, Buscombe JR, Griffiths MH, Semple SJG, Miller RF. Granulomatous Pneumocystis carinii pneumonia in a patient with the acquired immunodeficiency syndrome. Thorax 1990;45:769-71.

3 Foley NM, Griffiths MH, Miller RF. Histologically atypical Pneumocystis carinii pneumonia. Thorax 1993;48:9961001.

4 Miller RF, Pugsley WB, Griffiths MH. Open lung biopsy for investigation of acute respiratory episodes in patients with HIV infection and AIDS. Genitourinary Med 1995 (in press).

5 Travis WD, Lack EE, Ognibene FP. Lung biopsy interpretation in the acquired immunodeficiency syndrome: experience of the National Institutes of Health with literature review. Progress in AIDS Pathology 1989;1:51-84.

6 Oldham SAA, Castillo M, Jacobson FL, Mones JM, Saldana MJ. HIV-associated interstitial pneumonia: radiologic manifestations and pathologic correlation. Radiology manifestations

7 Suffredini AF, Ognibene FP, Lack EE, Simmons JT, Brenner M, Gill VJ, et al. Nonspecific interstitial pneumonitis: a common cause of pulmonary disease in the acquired immunodeficiency syndrome. Ann Intern Med 1987;107: 7-13.

8 Ognibene FP, Masur H, Rogers P, Travis WD, Suffredini $\mathrm{AF}$, Fuerstein I, et al. Nonspecific interstitial pneumonitis without evidence of Pneumocystis carinii in asymptomatic patients infected with human immunodeficiency virus (HIV). Ann Intern Med 1988;109:874-9.

9 Solal-Celigny P, Conderc LJ, Herman D, Herve P, SchaffarDeshayes L, Brun-Vezinet F, et al. Lymphoid interstitial Deshayes $\mathrm{L}$, Brun-Vezinet $\mathrm{F}$, et al. Lymphoid interstitial
pneumonitis in acquired immunodeficiency syndromerelated complex. Am Rev Respir Dis 1985;131:956-60.

10 Grieco MH, Chinoy-Acharya P. Lymphocytic interstitial pneumonia associated with the acquired immune deficiency syndrome. Am Rev Respir Dis 1985;131:952-5.

11 Lin Re Y, Gruber PJ, Saunders R, Perla EN. Lymphocytic interstitial pneumonitis in adult HIV infection. $N Y$ State f Med 1988;88:273-6.

12 Couderc L-J, D'Agay M-F, Danon F, Harzig M, Brocheriou immunodeficiency virus. Arch Intern Med 1987;147:98991 .

13 Carrington CB, Leibow AA. Lymphocytic interstitial pneumonia (abstract). Am F Pathol 1966;48:36.

14 Church JA, Isaacs H, Saxon A, Keens TG, Richards W. Lymphoid interstitial pneumonitis and hypogammaglobulinemia in children. Am Rev Respir Dis 1981;124: $491-6$.

15 Joshi VV, Oleske JM, Minnefor AB, Saad S, Klein KM, Singh $\mathrm{R}$, et al. Pathologic pulmonary findings in children with the acquired immunodeficiency syndrome: a study of ten cases. Hum Pathol 1985;16:241-6.

16 Joshi VV, Oleske JM. Pulmonary lesions in children with the acquired immunodeficiency syndrome: a reappraisa based on data in additional cases and follow up study of previously reported cases (letter). Hum Pathol 1986;17: 641-2. 
17 Andiman WA, Martin K, Rubinstein A, Pahwa S, Eastman $\mathrm{R}$, Katz BZ, et al. Opportunistic lymphoproliferations associated with Epstein-Barr viral DNA in in
children with AIDS. Lancet 1985;ii:1390-3.

18 Itescu S, Brancato J, Buxbaum J, Gregersen PK, Rizk CC Groxson TS, et al. A diffuse infiltrative CD8 lymphocytosis syndrome in human immunodeficiency virus (HIV) infection: a host immune response associated with HLADR5. Ann Intern Med 1990;112:3-10.

19 Rubinstein A, Morecki R, Silverman B, Charytan M, Krieger $\mathrm{BZ}$, Andiman W, et al. Pulmonary disease in childre with the acquired immunodeficiency syndrome and AIDSrelated complex. F Pediatr 1986;108:498-50.

20 Ettensohn DB, Mayer KH, Kessimian N, Smith PS. Lymphocytic bronchiolitis associated with HIV infection. Chest 1988;93:201-2.

21 Youssem SA, Colby TV, Carrington CB. Follicular bronchitis/bronchiolitis. Hum Pathol 1985;16:700-6.

22 Travis WD, Fox CH, Devaney KO, Wiess LM, O'Leary TJ, Ognibene FP, et al. Lymphoid pneumonitis in 50 adult patients infected with the human immunodeficiency virus: lymphocytic interstitial pneumonitis versus nonspecific interstitial pneumonitis. Hum Pathol 1992;23: $529-41$.

23 Semenzato G, Agostini C. Human retroviruses and lung involvement. Am Rev Respir Dis 1989;139:1317-22.

24 Guillon J-M, Autran B, Denis M, Fouret P, Plata F, May- naud CM, et al. Human immunodeficiency virus-related lymphocytic alveolitis. Chest 1988;94:1264-70.

25 Autran B, Maynaud CM, Raphael M, Plata F, Denis M Bourgin A, et al. Evidence for a T-lymphocyte alveolitis Bourgin A, et al. Evidence for a T-lymphocyte alveolitis
in human immunodeficiency virus-infected patients. AIDS in human immun

26 Plata F, Autran B, Martins LP, Wain-Hobson S, Raphael $M$, Maynaud CM, et al. AIDS virus-specific cytotoxic T lymphocytes in lung disorders. Nature 1987;328:348-51.

27 Resnick L, Pitchenik AE, Fisher E, Croney R. Detection of HTLV-11/LAV-specific IgG and antigen in bronchoalveolar lavage fluid from the patients with lymphocytic interstitial pneumonitis associated with AIDS-related complex. Am f Med 1987;82:553-6.

28 Ziza JM, Brun-Venet A, Rouzioux LH, Traversat J, IsraelBiet B, Barre-Sinoussi F, et al. Lymphadenopathy-associated virus isolated from bronchoalveolar lavage fluid in AIDS-related complex with lymphoid interstitial pneumonitis. $N$ Engl f Med 1985;313:183.

29 Chayt KJ, Harper ME, Marselle LM, Lewis EB, Rose RM, Oleske JM, et al. Detection of HTLV-111 RNA in the lungs of patients with AIDS and pulmonary involvement. fAM $A$ 1986;256:2356-9.

30 Linnemann CC, Baughmann RP, Frame PT, Floyd R. Recovery of human immunodeficiency virus and detection of 224 antigen in bronchoalveolar lavage fluid from adult patients with AIDS. Chest 1989;96:64-7. 